\title{
Estimating Energy Content of Municipal Solid Waste by Multiple Regression Analysis
}

\author{
Nwankwo, C. A. ${ }^{1}$, Amah, V. E. ${ }^{2}$ \\ ${ }^{1,2}$ University of Port Harcourt, Department of Environmental Engineering, P.M.B. 5323, Port Harcourt, Rivers State, Nigeria
}

\begin{abstract}
The ultimate disposal of Municipal Solid Waste is the landfill and when not properly disposed of can contribute to environmental pollution. However, energy can be recovered from solid waste through thermal processes. Two empirical models -a linear model and an exponential model - are proposed for use in estimating the energy content (kJ/kg) of solid waste generated from Rumuokoro market in Port Harcourt Nigeria. These models are derived from statistical multiple regression analysis of the percentage waste composition from the waste stream. The linear model $\mathrm{H}=a_{0}+a_{1}(F)+a_{2}(L)+a_{3}(M o)+a_{4}(P)+a_{5}(P l)+a_{6}(T)+a_{7}(W)$ gave a coefficient of correlation as 0.999 and the exponential model $\mathrm{H}=a_{0} W^{a_{1}} F^{a_{2}} L^{a_{3}} \mathrm{Mo}^{a_{4}} P^{a_{5}} P^{a_{6}} T^{a_{7}}$ gave a coefficient of correlation as 0.994. At 95\% confidence level for both models, the results were within acceptable limits and the null hypothesis is accepted.
\end{abstract}

Keywords: Municipal Solid Waste, Empirical Models, Multiple Regression Analysis, Energy content, correlation

\section{Introduction}

Waste management policy in Nigeria is hardly based on the waste treatment hierarchy of source reduction, recycling, treatment and ultimate disposal. Mostly, the last option for the management of waste (ultimate disposal) is what is commonly practiced by households in Nigeria. Both biodegradable and non-biodegradable fractions of the waste generated end up in the refuse dump sites since waste are hardly segregated. For the Nigerian economy to gain the benefits of alternative sources to energy there is need to invest in waste management using appropriate technology.

As part of sustainable waste management strategy, most western countries are reducing the amount of biodegradable waste that go to landfills. For example the European Council Directive (1991/31/EU) on landfill of wastes mandates member states to reduce the amount of biodegradable municipal waste deposited at landfill to $35 \%$ over fifteen year period starting since 1999. It is estimated that $50-60 \%$ of the municipal solid waste generated in Nigeria is organic, [1], [2]. This has been attributed to our cultural heritage in foods and lack of preserving facilities. One of the challenges of landfilling biodegradable waste is the emission of greenhouse gases such as carbon dioxide and methane which contribute to global warming [3] - [5].

The calorific values of some biodegradable waste have been investigated. Similarly [2] reported $1.733 \mathrm{Kcal} / \mathrm{g}$ (7.251 $\mathrm{MJ} / \mathrm{kg}$ ) as the cumulative energy content of Municipal Solid Waste (MSW) in some zones within Port Harcourt metropolis. However, studies involving the energy contents of waste have not been undertaken for any of the markets within Port Harcourt metropolis. The local markets in Nigeria are key players in terms of waste generation primarily due to lack of preserving/storage facilities which encourage disposal of large quantities of organic waste such as fruits and vegetables to dumpsites around the market areas. The total waste generated from Rumuokoro market was characterised based on percentage composition which comprises a wider range of components rather than being grouped as combustible and non-combustible waste. This allowed for a model employed in estimatingthe higher heating values of the waste.

The aim of this work is to develop empirical models for estimating energy content of municipal solid waste using the percentage compositions of the organic components. Multiple regression analysis has been used to develop a linear and an exponential equation.

\section{Materials and Methods}

\subsection{Composition of waste}

The volume and weight are used for the measurement of solid waste quantities. The samples were weighed and their compositions determined on the basis of their organic and inorganic contents. Field surveys of the final dumpsite were undertaken two times in a week for five weeks.

The weight of the empty truck was obtained from the refusedisposal company while the weight of the truck load was obtained at the dumpsite from the weighing bridge at the dumpsite. To determine the composition of the solid waste a pre-weighed 10-liter bucket was used to collect and weigh the refuse. Each full bucket was put on a weighing scale to determine the weight of the waste. After weighing, sorting of the waste was done accordingly and their individual compositions determined on the basis of their organic and inorganic contents. This was done for 10 days within a 5 week period. The composition of different waste components generated from Rumuokoro market is represented in Figure 1. 


\section{International Journal of Science and Research (IJSR) \\ ISSN (Online): 2319-7064}

Index Copernicus Value (2013): 6.14 | Impact Factor (2015): 6.391

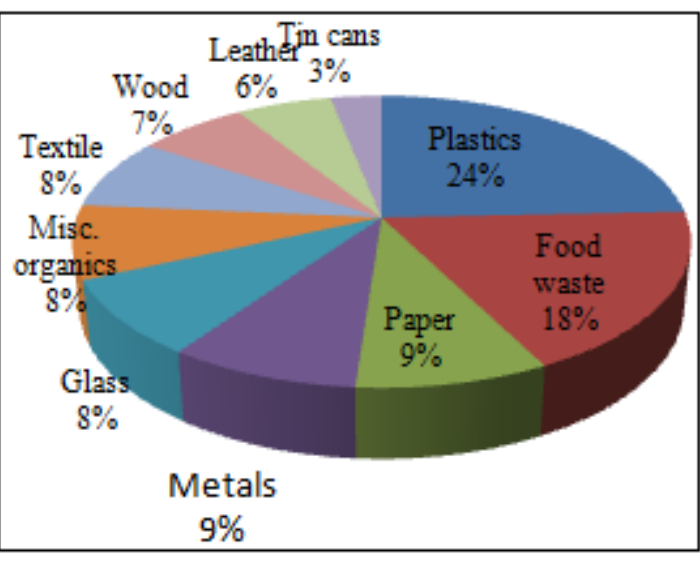

Figure 1: Composition of solid waste generated from Rumuokoro market

\subsection{Model Conceptualization}

Higher heating values were calculated using Dulong's formula as presented by [6] and shown by Equation 1. This formula takes into account the fractions of elements making up the components which are basically Carbon, Hydrogen, Oxygen, Nitrogen, Sulphur and Ash.

$$
\mathrm{H}=32,851 \mathrm{C}+141,989\left(\mathrm{H}-\frac{o}{8}\right)+9263 \mathrm{~S}
$$

[7] Howeverpresents a modified Dulong's formula as shown in Equation 2:

$$
\mathrm{H}=337 \mathrm{C}+1428\left(\mathrm{H}-\frac{o}{8}\right)+9 \mathrm{~S}
$$

[8]Shows the importance of Nitrogen in aerobic biological processes. Hence a modified Dulong'sequation is presented with fraction of Nitrogen being a component of the Equation 3 .

$$
\mathrm{H}=337 \mathrm{C}+1419\left(\mathrm{H}_{2}-0.125 \mathrm{O}_{2}\right)+93 \mathrm{~S}+23 \mathrm{~N}
$$

Equation 4 consisting purely of the percent composition of components was developed and can be used to estimate the energy content of solid waste [8], [9].

$$
\mathrm{H}=0.051[\mathrm{~F}+3.6(\mathrm{CP})]+0.352(\mathrm{PLR})
$$

Where $\mathrm{F}=\%$ of food by weight
$\mathrm{CP}=\%$ of cardboard and paper by weight

$\mathrm{PLR}=\%$ of Plastics and rubber by weight.

An equation was developed by [10] using statistical analysis data for a variety of materials as reported in a number of sources. The model takes into account the mass fractions of carbon, hydrogen, oxygen, chlorine, and sulphur content of the material being combusted. It is as presented below, Equation 5:

$$
\mathrm{H}=-791+17,050 \mathrm{C}+32,030\left(\mathrm{H}-\frac{O}{8}-\frac{C l}{35.5}\right)+4,591 \mathrm{~S}
$$

[11]Conducted a multiple regression analysis to develop an equationfor predicting the energy content of the municipalsolid waste from Kaohsiung City, Taiwan. The equation as represented in Equation 6 includespercent compositions of the elements $\mathrm{C}, \mathrm{H}, \mathrm{O}, \mathrm{N}, \mathrm{S}$, and water as independent variables.

$$
\mathrm{H}=1,558.80+19.96(\% \mathrm{C})+44.30(\% \mathrm{O})-671.82(\% \mathrm{~S})-19.92
$$

$$
(\% \mathrm{~W})
$$

The role of water content in calculating energy content is also seen in the multiple regression analysis done by [12]. A multiple non linear equation was developed shown as Equation 7

$$
\mathrm{H}=\left(1-\mathrm{H}_{2} \mathrm{O} / 100\right)(0.327 \mathrm{C}+1.241 \mathrm{H}-0.089 \mathrm{O}-0.26 \mathrm{~N}+
$$

The research carried out by [13] reveal that energy content of solid can be estimated with an equation containing the fraction of carbon from the organic constituents and the carbonate carbon content (Equation 8).

$$
\mathrm{H}=14096 \mathrm{C}_{\text {org }}+60214(\mathrm{H}-\mathrm{O} / 8)+3982 \mathrm{~S}-6382 \mathrm{C}_{\text {inorg }}
$$

Table 1 shows the heating value of the waste for the different days on which waste samples were collected.

Table 1: Heating values based on Dulong's formula

\begin{tabular}{|c|c|c|c|c|c|c|c|c|}
\hline & Plastics & Food wastes & Paper & Misc. org & Textile & Wood & Leather & Heating Value $(\mathrm{kJ} / \mathrm{kg})$ \\
\hline Day 1 & 28.159 & 25.970 & 4.577 & 4.975 & 6.368 & 9.154 & 2.388 & 22111.362 \\
\hline Day 2 & 19.317 & 17.659 & 5.073 & 13.073 & 7.317 & 7.805 & 7.122 & 22034.750 \\
\hline Day 3 & 23.814 & 13.843 & 7.260 & 8.616 & 9.874 & 0.000 & 8.422 & 23071.509 \\
\hline Day 4 & 21.816 & 23.876 & 9.831 & 5.993 & 4.869 & 14.045 & 7.772 & 21602.932 \\
\hline Day 5 & 25.759 & 12.145 & 8.521 & 11.851 & 9.403 & 0.000 & 5.093 & 22471.974 \\
\hline Day 6 & 28.603 & 14.634 & 16.741 & 6.984 & 9.424 & 0.000 & 2.993 & 21709.857 \\
\hline Day 7 & 19.591 & 16.764 & 10.331 & 7.797 & 9.064 & 9.259 & 6.530 & 21662.366 \\
\hline Day 8 & 19.291 & 13.091 & 9.350 & 5.217 & 10.039 & 11.024 & 9.941 & 22290.783 \\
\hline Day 9 & 28.558 & 16.058 & 7.885 & 9.808 & 8.269 & 6.635 & 5.577 & 22329.880 \\
\hline Day 10 & 28.063 & 25.988 & 7.708 & 6.818 & 4.150 & 8.004 & 6.423 & 22204.896 \\
\hline
\end{tabular}

Multiple regression analysis is used for higher heating value estimation. The trend in modelling is to collate data, establish relations via mathematical equations, and calibrate such equation in the way of assigning values to associated constants and adopting such equation for predictions [14], [15]. A linear and exponential model will be used to estimate heating values from the percentage compositions of the waste components with the calculated Dulong's heating values as target. The model will be of the form:

$\mathrm{H}=\mathrm{f}$ (Plastics, Food waste, paper, Misc organics, textile, wood, leather)
The above expression can be expressed linearly (Equation 9) and exponentially(Equation 10) as:

$\mathrm{H}=\mathrm{a}_{\mathrm{o}}+\mathrm{a}_{1}(\mathrm{~F})+\mathrm{a}_{2}(\mathrm{~L})+\mathrm{a}_{3}(\mathrm{Mo})+\mathrm{a}_{4}(\mathrm{P})+\mathrm{a}_{5}(\mathrm{Pl})+\mathrm{a}_{6}(\mathrm{~T})+$ $\mathrm{a}_{7}(\mathrm{~W})(9)$

$\mathrm{H}=\mathrm{a}_{0} W^{a_{1}} F^{a_{2}} L^{a_{3}} M^{a_{4}} P^{a_{5}} P^{a_{6}} T^{a_{7}}(10)$

Where: $\mathrm{H}$ is the predicted Dulong's higher heating value $(\mathrm{kJ} / \mathrm{kg})$

$\mathrm{W}=\% \mathrm{Wood}$

$\mathrm{F}=\%$ Food waste

$\mathrm{L}=\%$ Leather

Mo $=\%$ Miscellaneous organics

\section{Volume 5 Issue 6, June 2016 www.ijsr.net}




\section{International Journal of Science and Research (IJSR)}

ISSN (Online): 2319-7064

Index Copernicus Value (2013): 6.14 | Impact Factor (2015): 6.391

$\mathrm{P}=\%$ Paper

$\mathrm{Pl}=\%$ Plastics

$\mathrm{T}=\%$ Textile

$\mathrm{a}_{\mathrm{o}}$ to $\mathrm{a}_{7}$ are coefficients of regression

To estimate the coefficients of regression from the exponential model, Equation 10 is first linearized as Equation 11:

$$
\begin{array}{r}
\operatorname{InH}=\ln \mathrm{a}_{\mathrm{o}}+\mathrm{a}_{1} \ln \mathrm{W}+\mathrm{a}_{2} \ln \mathrm{F}+\mathrm{a}_{3} \operatorname{InL}+\mathrm{a}_{4} \operatorname{lnMo}+\mathrm{a}_{5} \ln \mathrm{P}+ \\
\mathrm{a}_{6} \ln \mathrm{Pl}+\mathrm{a}_{7} \mathrm{~T}
\end{array}
$$

Let $\ln \mathrm{a}_{\mathrm{o}}=\mathrm{b}$

Therefore $\mathrm{a}_{\mathrm{o}}=\exp (\mathrm{b})$

The final linear Equation is represented as Equation 12:

$\operatorname{InH}=\mathrm{b}+\mathrm{a}_{1} \ln \mathrm{W}+\mathrm{a}_{2} \ln \mathrm{F}+\mathrm{a}_{3} \operatorname{InL}+\mathrm{a}_{4} \ln \mathrm{Mo}+\mathrm{a}_{5} \ln \mathrm{P}+\mathrm{a}_{6} \ln \mathrm{Pl}$ $+\mathrm{a}_{7} \mathrm{~T}$

Regressit [16] an addin to Microsoft Excel was used in the regression analysis to estimate the coefficients. $\mathrm{T}$ - test was done at $95 \%$ confidence level.

\section{Results and Discussion}

The coefficients of linear multiple regression are given in Table 2. The regression coefficient values are used toobtain Equation13 for energy content estimation.

Table 2: Linear regression coefficient results

\begin{tabular}{|c|c|c|c|}
\hline Variable & Coefficient & t-Stat. & $P$-value \\
\hline Intercept & 22,402 & 23.611 & 0.002 \\
\hline Food_wastes & -25.677 & -1.523 & 0.267 \\
\hline Leather & 122.132 & 9.414 & 0.011 \\
\hline Misc._organics & -56.697 & -4.354 & 0.049 \\
\hline Paper & -104.471 & -15.508 & 0.004 \\
\hline Plastic & 49.728 & 7.415 & 0.018 \\
\hline Textile & 4.442 & 0.123 & 0.913 \\
\hline Wood & -64.129 & -13.907 & 0.005 \\
\hline
\end{tabular}

$\mathrm{H}=22,402-25.677 \mathrm{~F}+122.132 \mathrm{~L}-56.697 \mathrm{MO}-$ 104.471 P + 49.728Pl + 4.442 T - 64.129 W

The coefficients of the exponential multiple regression are presented in Table 3. The values are used to produce Equation 14.

Table 3: Exponential regression coefficient results

\begin{tabular}{|c|c|c|c|}
\hline Variable & Coefficient & $t$-Stat. & $P$-value \\
\hline Intercept & 9.782 & 85.884 & 0.000 \\
\hline Wood & -0.009397 & -5.327 & 0.033 \\
\hline Food waste & -0.006333 & -0.348 & 0.761 \\
\hline Leather & 0.041 & 8.135 & 0.015 \\
\hline Misc. organics & -0.019 & -4.004 & 0.057 \\
\hline Paper & -0.044 & -11.056 & 0.008 \\
\hline Plastics & 0.084 & 7.176 & 0.019 \\
\hline Textile & 0.025 & 1.790 & 0.215 \\
\hline
\end{tabular}

$\mathrm{H}=17712.04 W^{-0.0094} F^{-0.0063} L^{0.041} M o^{-0.019} P^{-0.044} P l^{0.084} T^{0.025}$

Equation 14 can be rewritten as Equation 15:

$$
\mathrm{H}=\frac{17712.04 L^{0.041} \mathrm{Pl}^{0.084} \mathrm{~T}^{0.025}}{W^{0.0094} \mathrm{~F}^{0.0063} \mathrm{MO} \mathrm{O}^{0.019} P^{0.044}}
$$

\subsection{Model Verification \\ 3.1.1 Linear Model}

Figure 2 shows a graphical comparison of the estimated heating value using the linear empirical model derived and the calculated heating value.

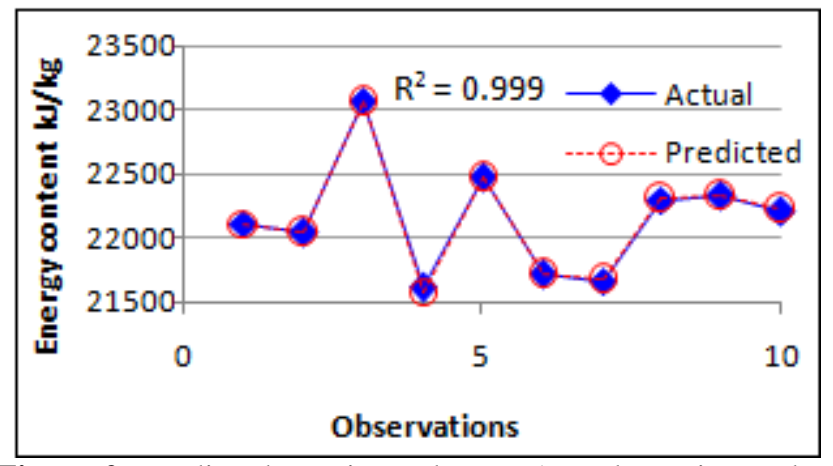

Figure 2: Predicted Heating value Vs Actual Heating Value

As can be seen the model fits well appearing to lie almost on top of the Actual calculated value. The coefficient of correlation " $\mathrm{R}$ " ' between the actual calculated heating value and the predicted heating value is 0.999. This high coefficient of correlation indicates the reliability of the model in estimating the heating value.A null hypothesis " $\mathrm{H}_{\mathrm{o}}$ " of equal mean and an alternate hypothesis " $\mathrm{H}_{1}$ " of unequal mean are to be tested. A t statistic test was done at 95\% confidence level andthe results obtained were within acceptable limit,hence the null-hypothesis is accepted. Table 4 shows the absolute residuals value sorted from largest to smallest.

Table 4: Values of residuals of linear model from largest to smallest (Absolute values)

\begin{tabular}{|c|c|c|c|}
\hline Observations & Actual & Predicted & Residual \\
\hline 4 & 21,603 & 21,577 & 25.684 \\
\hline 10 & 22,205 & 22,228 & -23.351 \\
\hline 3 & 23,072 & 23,056 & 15.047 \\
\hline 8 & 22,291 & 22,305 & -13.771 \\
\hline 9 & 22,330 & 22,323 & 7.270 \\
\hline 7 & 21,662 & 21,669 & -6.199 \\
\hline 2 & 22,035 & 22,040 & -5.223 \\
\hline 1 & 22,111 & 22,108 & 3.049 \\
\hline 6 & 21,710 & 21,711 & -1.508 \\
\hline 5 & 22,472 & 22,473 & -0.997 \\
\hline
\end{tabular}

It can be seen from Table 4that the highestresidual value occurs on day 4 with as high as 25.684 . These residuals simply show by how much the actual value varies from the predicted values on the sampling day. This variation is compensated for by the high coefficient of correlation.

\subsubsection{Exponential Model}

Figure 3 presents a comparison of the estimated heating value using the exponential model and the calculated heating value.

\section{Volume 5 Issue 6, June 2016 www.ijsr.net}




\section{International Journal of Science and Research (IJSR) \\ ISSN (Online): 2319-7064}

Index Copernicus Value (2013): 6.14 | Impact Factor (2015): 6.391

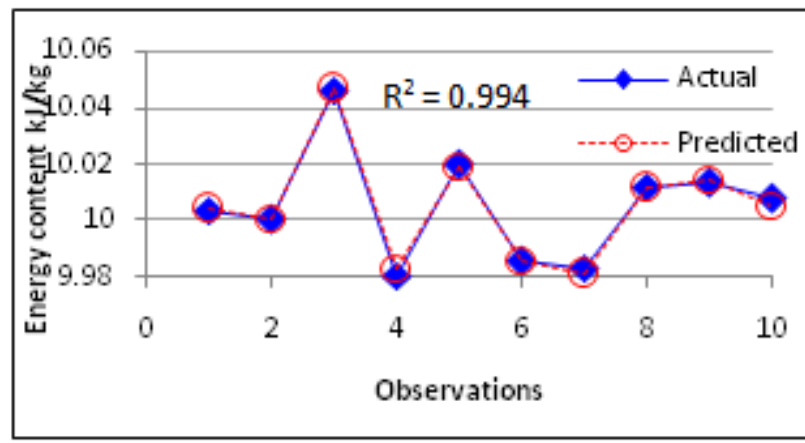

Figure 3: Predicted Heating value Vs Actual Heating Value

The good appearance of Figure 3 shows the exponential model fits well too. The coefficient of correlation " $\mathrm{R}$ ", between the calculated heating value and the predicted heating value is 0.994 . A null hypothesis " $\mathrm{H}_{\mathrm{o}}$ " of equal mean and an alternate hypothesis " $\mathrm{H}_{1}$ " of unequal meanwere tested. A t statistic test was done at 5\% level of significance and the results obtained were within acceptable limits. Hence, the null-hypothesis is accepted. Table 5 shows the residuals sorted from largest to smallest from absolute values.
Table 5: Values of residuals of exponential model from largest to smallest (Absolute values)

\begin{tabular}{|c|c|c|c|}
\hline Observations & Actual & Predicted & Residual \\
\hline 4 & 21602.93 & 21663.66 & -60.723 \\
\hline 10 & 22204.9 & 22147.9 & 56.994 \\
\hline 7 & 21662.37 & 21616.2 & 46.167 \\
\hline 9 & 22329.88 & 22356.81 & -26.928 \\
\hline 5 & 22471.97 & 22460.69 & 11.279 \\
\hline 2 & 22034.75 & 22045.67 & -10.920 \\
\hline 3 & 23071.51 & 23082.15 & -10.645 \\
\hline 6 & 21709.86 & 21719.35 & -9.491 \\
\hline 8 & 22290.78 & 22283.18 & 7.605 \\
\hline 1 & 22111.36 & 22114.48 & -3.115 \\
\hline
\end{tabular}

It can be seen from Table 5 that the highest residual value occurs on day 4 same as the linear model with a value as high as 60.723. This residual is higher than that of the linear model.However, the high correlation coefficient makes this model useful. The linear model is nonetheless better because of its higher correlation coefficient and better goodness of fit.

\subsection{Correlation coefficients of different components in the waste stream}

Table 6 presents the correlation coefficients between different components in the waste stream.

As observed in Table 6, the level of correlation between the individual components is high and this shows that each component contributes significantly to the overall performance of the model derived.

Table 6: Correlation Matrix of Coefficient Estimates

\begin{tabular}{|c|c|c|c|c|c|c|c|}
\hline Variable & Food_wastes & & & & & & \\
\hline Food_wastes & 1.000 & Leather & & & & & \\
\hline Leather & 0.872 & 1.000 & Misc._organics & & & & \\
\hline Misc._organics & 0.917 & 0.835 & 1.000 & Paper & & & \\
\hline Paper & 0.854 & 0.784 & 0.871 & 1.000 & Plastic & & \\
\hline Plastic & 0.661 & 0.798 & 0.754 & 0.619 & 1.000 & Textile & \\
\hline Textile & 0.977 & 0.859 & 0.919 & 0.822 & 0.735 & 1.000 & Wood \\
\hline Wood & 0.375 & 0.384 & 0.582 & 0.445 & 0.723 & 0.505 & 1.000 \\
\hline
\end{tabular}

\section{Conclusions and Recommendations}

It can be concluded that the linear and exponential model concepts formulated can be used in predicting heating values from the percentage compositions of various components in a solid waste stream. A high level of correlation is observed if the regression coefficients are estimated from the solid waste data from a particular source. This is so because it is purely statistical and can only be applied with such a high measure of correlation to solid waste gotten from the source being considered. Based on statistical tests performed on the linear and exponential model, the authors concluded that a good general formula for predicting energy content of solid wastes generated from Rumuokoro market is the linear form expressed as:

$\mathrm{H}=22,402-25.677 \mathrm{~F}+122.132 \mathrm{~L}-56.697 \mathrm{MO}-104.471 \mathrm{P}$ $+49.728 \mathrm{Pl}+4.442 \mathrm{~T}-64.129 \mathrm{~W}$

Where $\mathrm{H}$ is higher heating value in $\mathrm{kJ} / \mathrm{kg}$. F, L, MO, P, Pl, T, $\mathrm{W}$ are percentage composition of Food waste, leather, miscellaneous organics, paper, plastics, textile and wood respectively.
It is recommended that for future studies, data should be collected seasonally. A wider range of components should be considered when characterizing solid waste and not merely grouped as combustible and non combustible waste. More data and a wider range of waste characterization will improve the effectiveness of future models in predicting heating values from different sources.

\section{References}

[1] C. A. Nwankwo, E. I. Stentiford, L. A. Fletcher, "Use of Compost to Enhance the Growth of Tomatoes in Soil contaminated with Nigerian Crude Oil," Journal of Applied Sciences 14(19): 2391 - 2395, 2014.

[2] A. H. Igoni, M. J. Ayotamuno, S. O. T. Ogaji,S. D. Probert, "Municipal Solid Waste in Port Harcourt, Nigeria,” Applied Energy 84(2007): 664 - 670, 2007.

[3] J. M.Baldasano, C. Soriano, "Emission of Greenhouse Gases from Anaerobic Digestion Processes: Comparison with other Municipal Solid Waste 
Treatments". Water Science and Technology, 41(3):275-82, 2000.

[4] J. M. Baldasano, C. Soriano, L. Boada, "Emission Inventory for Greenhouse Gases in the City of Barcelona, 1987 - 1996," Atmospheric Environment 33(23): 3765-3775, 1999.

[5] W. Irving, J. Woodbury, M. Gibbs, D. Pape, V. Bakshi, "Applying a correction factor to the IPCC default methodology for estimating National Methane Emissions from Solid Waste Disposal Sites," Waste Management and research 17(6): 459-464, 1999.

[6] A. P. Sincero, G. A. Sincero,"Environmental Engineering a Design Approach". U. S. Edition. Prentice Hall of India, New Delhi. 2006. Pg 524.

[7] H. S. Peavy, D. R. Rowe, G. Tchobanoglous, "Environmental Engineering," International Edition, McGraw-Hill, New York, 1985. Pg 585.

[8] G. Kiely, "Environmental Engineering," International Editions, McGraw Hill, New York, 1998. Pp 640.

[9] Z. A. Khan, Z. H.Abu-Ghurrah, "New approaches for estimating energy content in MSW," ASCE Journal of Environmental Engineering. 117(3): 376 - 380, 1991.

[10]C. D. Cooper, K.Brian,J.MacDonald, "Estimating the Lower HeatingValues of Hazardous and Solid Wastes," Journal of the Air \& Waste Management Association, 49(4): 471-476, 1999.

[11] J. I. Liu, R. D. Paod, T. M. Holsen, "Modelling the energy content of municipal solid waste using multiple regression analyses," Journal of the Air \& Waste Management Association 46 (7): 650-656, 1996.

[12]E. Akkaya, A. Demir, "5th International Advanced Technologies Symposium (IATS'09”), May 13-15, 2009, Karabuk, Turkey

[13] D. L. Wilson, "Prediction of heat of combustion of solid wastes from ultimate analysis," Environmental Science\& Technology 6 (13): 1119-1121, 1972.

[14] I. L. Nwaogazie, "Probability and Statistics for Science and Engineering Practice," 2nd Edition, University of Port Harcourt Press, Nigeria, 2006, Pg 107.

[15]A. K. Majumder, R. Jain, P. Banerjee, J. P. Barnwal,"Development of a new proximate analysis based correlation to predict calorific value of coal," Fuel 87(2008): 3077-3081, 2008.

[16] R. Nau, J. Butler, "Regressit (Version 2.2.2)," Fuqua School of Business, Duke University and McCombs School of Business, University of Texas. Release date May 7, 2015

\section{Author Profile}

Dr Chindo, Nwankwo holds a PhD in Environmental Engineering from the University of Leeds. Her research focuses on several interconnected areas including bioremediation of contaminated land and groundwater, Water Sanitation and Hygiene (WASH) and waste management. Her works are published in high ranking journals

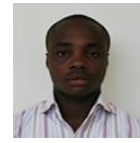

Amah, Victor holds a Masters in Environmental Engineering. $\mathrm{He}$ is an assistant lecturer at the Department of Environmental Engineering, University of Port Harcourt. $\mathrm{He}$ is well experienced in engineering safety. His research interest is in noise pollution and air quality. He has published some of his works.

Volume 5 Issue 6, June 2016 www.ijsr.net 